\title{
Modeling the Influence of Roundabout Deflection on Its Efficiency as a Noise Abatement Measure
}

\author{
Saša Ahac *(D), Maja Ahac *, Josipa Domitrović and Vesna Dragčević \\ Faculty of Civil Engineering, University of Zagreb, 10000 Zagreb, Croatia; josipa.domitrovic@grad.unizg.hr (J.D.); \\ vesna.dragcevic@grad.unizg.hr (V.D.) \\ * Correspondence: sasa.ahac@grad.unizg.hr (S.A.); maja.ahac@grad.unizg.hr (M.A.)
}

check for

updates

Citation: Ahac, S.; Ahac, M.; Domitrović, J.; Dragčević, V.

Modeling the Influence of

Roundabout Deflection on Its

Efficiency as a Noise Abatement

Measure. Sustainability 2021, 13, 5407.

https://doi.org/10.3390/su13105407

\section{Academic Editors:}

Elżbieta Macioszek, Anna Granà, Tomaž Tollazzi and Tullio Giuffrè

Received: 19 April 2021

Accepted: 10 May 2021

Published: 12 May 2021

Publisher's Note: MDPI stays neutral with regard to jurisdictional claims in published maps and institutional affiliations.

Copyright: (C) 2021 by the authors Licensee MDPI, Basel, Switzerland. This article is an open access article distributed under the terms and conditions of the Creative Commons Attribution (CC BY) license (https:/ / creativecommons.org/licenses/by/ $4.0 /)$.

\begin{abstract}
Challenges that emerge in roundabout design are mostly related to space constrictions and provision of appropriate deflection around the central island. This can result in speed profiles on roundabouts that might reduce their potential as a noise abatement measure. Because of this, the impact of a roundabout on noise levels and its applicability as a traffic calming device and a noise abatement measure should be investigated in the early design stage, by modeling noise levels. In this paper, the following hypothesis is tested: vehicle movement trajectories, defined during the fastest path performance check in roundabout early design phase, can be used as the road traffic noise sources when modeling noise at roundabouts using static noise model. This procedure (1) simplifies the preparation of the noise model, (2) results in a model that is closer to the real-world in terms of traffic flow conditions, (3) allows the noise calculations in the early stages of roundabout design, and (4) includes the influence of roundabout deflection on calculated noise levels. The abovementioned simplifications of the road traffic noise modeling process should encourage the optimization of roundabout geometry in terms of its noise reduction capabilities in the preliminary design phase of these intersections.
\end{abstract}

Keywords: noise emission model; fastest path; relative speed

\section{Introduction}

Among various definitions of sustainable transportation, many experts use the following: "a sustainable transportation system is one that:

- Allows the basic access needs of individuals and societies to be met safely and in a manner consistent with human and ecosystem health, and with equity within and between generations.

- Is affordable, operates efficiently, offers a choice of transport mode, and supports a vibrant economy.

- Limits emissions and waste within the planet's ability to absorb them, minimizes consumption of non-renewable resources, limits consumption of renewable resources to the sustainable yield level, reuses and recycles its components, and minimizes the use of land and the production of noise" [1,2].

The goal of sustainable transportation is to protect the environment and conserve resources while taking into consideration societal needs as well as benefits and costs [3]. Numerous studies have shown that the abovementioned sustainability goals can be achieved in road traffic network planning, design, and management by the introduction of modern roundabouts in the road network. According to [3-17], these intersections have proven to be very successful at improving safety (due to the reduced number of conflict points and lower speed compared to the traditional intersections) while enhancing mobility by reducing the total delay compared to other controlled intersections. Moreover, modern roundabouts usually perform better than traditional intersections with traffic lights in terms of environmental sustainability. Previous studies have shown that the application 
of roundabouts can help reduce the excessive emissions and fuel consumption associated with idling time, acceleration, and deceleration of vehicles that usually occur on traditional intersections with traffic lights, as well as noise pollution in the vicinity of road intersections. Reported average reductions varied from 21 to $42 \%$ in emissions of carbon monoxide, $16-59 \%$ in emissions of carbon dioxide, $20-48 \%$ in emissions of oxides of nitrogen, $18-65 \%$ in emissions of hydrocarbons, and from 1 to $4 \mathrm{~dB}(\mathrm{~A})$ in noise emission [4,11,13-15,18-28].

Since noise pollution is still considered a major environmental health problem in Europe [29], and since road traffic is the dominant noise source in urban and suburban areas, the noise abatement opportunities should be an integral part of every road planning, design and/or reconstruction process. In urban areas, the average vehicle speed is low (50 km/h or lower), so the road traffic noise level is influenced by vehicle speed, acceleration, and deceleration $[20,30,31]$. To achieve a required reduction in noise levels, it is necessary to match the physical layout of the road to the intended speed and to provide as smooth a driving pattern as possible [20]. Modern roundabout, as a traffic calming device on which operating speed depends on the geometry (deflection around the circular island) [32,33], and a device that can carry smooth traffic flow by minimizing the start-stop operations of drivers, fulfills the abovementioned requirements for the effective noise abatement measure.

A smooth speed profile through the roundabout is achieved by ensuring the clarity of the situation for approaching drivers, visibility between road users, comprehensibility of traffic operations, and appropriate accommodation of the design vehicles. This means that the impact of a modern roundabout on noise reduction is directly linked to the quality of its design. Roundabout design is an iterative process that consists of the identification of initial design elements, performance checks (the design vehicle swept path analysis, the definition of the fastest path, and visibility tests), and final design details. A good design results in the smooth curvature, channelization, and deflection required to achieve consistent speeds, and appropriate sight distance. As mentioned above, to achieve the required reduction in vehicular emissions, the speed profile through the roundabout must be as smooth as possible [34-36]. This can be ensured in the roundabout's designing phase by conducting the abovementioned performance checks, specifically the definition of the fastest path through the roundabout. This performance check aims to determine the negotiation speed for a particular movement into, through, and exiting the roundabout, and the relative speed between consecutive geometric elements as well as between conflicting traffic movements. If the determined relative speed is high, large decelerations and accelerations will occur, which will result in negative impacts on drivers and on the road environment. Therefore, according to [32], the maximum relative speed on traffic calming devices such as roundabouts should be less than $20 \mathrm{~km} / \mathrm{h}$.

Environmental benefits of the introduction of modern roundabouts in the road network in terms of their noise reduction capabilities can be determined either by field measurements $[4,13-15,24,26,28,37-42]$ or by physical modeling, using established or new noise models that are verified by field measurements $[18,23,28,43-50]$. The most important attributes of traffic influencing the noise are traffic flow, vehicle speed, and percentage of heavy vehicles, and these attributes are incorporated in established traffic noise emission models to a varying degree of detail [51-54]. Problems that emerge while modeling noise at roundabouts relate primarily to capturing the impact of their specific traffic flow conditions in the noise emission model. These specific traffic flow conditions are minimized start-stop operations and queuing, as well as the smaller average speed of approaching and passing traffic compared to the traditional intersections with traffic lights.

Depending on the way noise models account for traffic flow, the temporal and spatial variations in vehicle kinematics at intersections are more-or-less accurately captured. In static noise models, roads are divided into sections where traffic flow is considered smooth and homogeneous. These noise models usually include a propagation correction term for noise levels in the vicinity of an intersection, the value of which depends on the distance to the intersection [51,52]. Analytic noise models attempt to capture the impact of interrupted 
traffic on the average vehicle speed profile. They split each road section into subsections where vehicles are assumed to have a constant average speed and homogeneous traffic flow conditions [52]. Dynamic noise models or micro-simulation noise models are based on a dynamic traffic model, and as such can capture the specific traffic flow conditions in the vicinity of intersections [52,55-60].

The usability of each noise model depends on its reliability and accuracy. According to the previous studies, static models usually underestimate the noise levels compared to the analytic and dynamic noise models [52]. On the other hand, previous studies have shown that the increased complexity of a model that includes more physical phenomena and effects will not automatically produce better results in terms of model accuracy $[53,61]$. The optimal model is one in which the reliability of the result is harmonized with the available input data, and the costs and time required to create a noise model. Based on that, a static noise model RLS-90 was selected as a baseline for road traffic noise calculations conducted in the research presented in this paper. Previous research showed that modifications of the standard RLS-90 model (described in Section 2) can result in the reduction of differences between measured and calculated noise levels ranging from 1.0 to $2.8 \mathrm{~dB}(\mathrm{~A})$ for streets and intersections $[62,63]$. However, the modifications concerning the position of noise sources showed to be too detailed and time-consuming when modeling traffic noise at roundabouts, especially roundabouts with more than one entry and exit lane. Another issue with these modifications is that they do not represent real traffic flow conditions at roundabouts, especially concerning the movement trajectories of vehicles negotiating these types of intersections.

The main aim of the research presented in this paper is to establish whether the modern roundabout design procedure (that includes the abovementioned performance checks) could be expanded to facilitate the evaluation process of the road traffic impact on the environmental noise levels in the vicinity of these intersections. The research is focused on the modification of the established RLS-90 method that will allow the modeling of the influence of roundabout design on the calculated noise levels. The modification includes the positioning of the noise sources on the movement trajectories derived from the roundabout fastest path performance check. The research results should provide answers to following questions: (1) whether the abovementioned noise model modification could be used in modeling the influence of roundabout deflection on its efficiency as a noise abatement measure; and (2) could this approach be useful for the assessment of the planned roundabout's impact on the environmental noise, since the fastest path performance check is conducted to assess a roundabout's safety performance in the early design phase.

\section{Materials and Methods}

The first part of the research presented in this paper was focused on the validation of modified RLS-90 noise models. RLS-90 noise model requires input data on the average hourly traffic flow, the percentage of heavy vehicles, the average speed for each vehicle group, the dimension, geometry, type of the road, and the road surface. Traffic data (average hourly traffic flow, the percentage of heavy vehicles, and the average speed) can be derived from the average annual daily traffic data and the type of road, or measured values can be included as calculation input [64]. All the above-mentioned data is readily available in the preliminary roundabout design phase, which gives RLS-90 model an advantage over other noise emission models. Following noise propagation influences are also considered: obstacles, vegetation, air absorption, reflection, and diffraction [51,65]. RLS-90 model is a static noise model, which means that traffic lanes are divided into sections where traffic flow is considered smooth and homogeneous [52]. Since this assumption does not hold in the vicinity of intersections, RLS-90 model includes a propagation correction term. Therefore, the sound pressure level for the street $\left(\mathrm{L}_{\mathrm{r}}\right)$ is given by:

$$
\mathrm{L}_{\mathrm{r}}=\mathrm{L}_{\mathrm{m}}+\mathrm{K},
$$


where $L_{m}$ is the mean A-weighted level and $K$ is the addition for the increased effect of traffic light-controlled intersections and other intersections. This value ranges from 0 to $3 \mathrm{~dB}(\mathrm{~A})$, depending on the proximity of the intersection to the receiver [65].

Previous research conducted on the University of Zagreb Faculty of Civil Engineering showed that the following modifications of the standard RLS-90 model (hereinafter referred to as VAR-1) improve the accuracy of calculated sound pressure levels for urban streets and intersections [62,63]:

- Noise sources are situated at $0.5 \mathrm{~m}$ above the road surface on the axis of each lane (according to RLS-90, they are situated above the axis of the external road lanes on multilane roads), and traffic load is divided equally over lanes.

- Heavy vehicles are vehicles with a total weight of over 3.5 tons (according to RLS-90, heavy vehicles are vehicles with a total weight over 2.8 tons).

- Periods "day", "night", and "evening" are defined in the accordance with the Environmental Noise Directive (END) [66] (in RLS-90, only two periods are defined: period "day", lasting from 6:00 to 22:00, and "night", lasting from 22:00 to 6:00).

During the research presented in [67], the modifications concerning the position of noise sources showed to be too detailed and time-consuming when modeling traffic noise at roundabouts, especially roundabouts with more than one entry and exit lane. Another issue with these modifications is that they do not represent real traffic flow conditions at roundabouts, especially concerning the movement trajectories of vehicles negotiating these types of intersections. Because of that, the research presented in this paper is focused on the additional modifications of RLS-90 method (hereinafter referred to as VAR-2):

- The addition for the increased effect of intersections $(K)$ is set to 0 .

- Noise sources are positioned on the movement trajectories derived from the roundabout fastest path performance check.

The fastest path performance check is conducted to determine theoretical attainable speeds of vehicles traversing through the roundabout entry, around the central island, and out the relevant exit $[68,69]$ during the roundabout design stage. The fastest path is defined as the smoothest, flattest path possible for a single vehicle negotiating a roundabout, in the absence of other traffic and ignoring all lane markings. It is represented by 3rd-degree splines (piecewise polynomials of 3rd degree with function values and 2nd derivatives that agree at the points where they join), with a safety lateral width of $1.5 \mathrm{~m}$ along all elevated curbs [70] (shown on Figure 1).

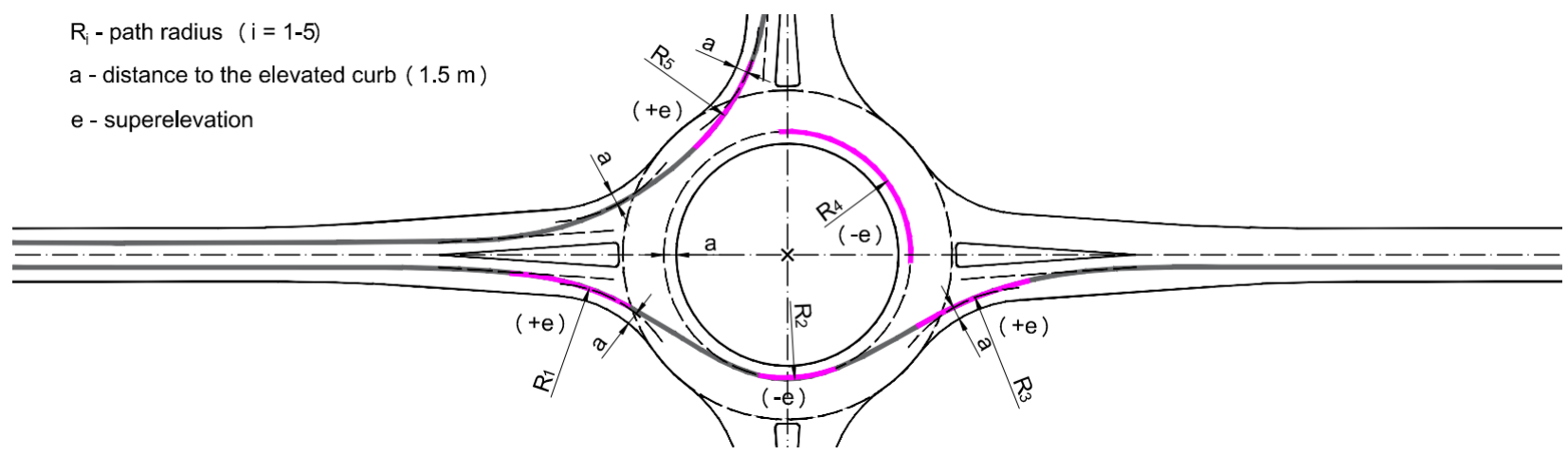

Figure 1. Fastest paths on a four-legged single-lane roundabout.

After the fastest path is defined, the minimum radii are determined, compared, and used in the estimation of vehicle speed. To achieve required entry $\left(V_{1}, V_{5}\right)$, circulating $\left(V_{2}\right.$, $\left.\mathrm{V}_{4}\right)$, and exit speeds $\left(\mathrm{V}_{3}\right)$, appropriate critical radii relationships for each approach must be achieved. Entry path radius $\left(R_{1}\right)$ must be larger than circulating path radii $\left(R_{2}\right.$ and $\left.R_{4}\right)$, but at the same time smaller than exit path radius $\left(R_{3}\right)$; also, circulating path radius $\left(R_{2}\right)$ must 
be smaller than exit path radius $\left(\mathrm{R}_{3}\right)$. Vehicle speed estimation is based on the following speed-radius relationship [68-71]:

$$
V_{i}=\sqrt{ }\left(127 \times R_{i} \times(f \pm e)\right),
$$

where $V_{i}(\mathrm{~km} / \mathrm{h})$ is the design speed (i=1-5), $R_{i}(m)$ is the fastest path minimum radius $(\mathrm{i}=1-5), \mathrm{f}(-)$ is the side friction factor defined in [71], and e $(\mathrm{m} / \mathrm{m})$ is the superelevation. The predicted speed values are used to assess a roundabout's safety performance and are used in the intersection and stopping sight distance computations. Fastest path performance checks include the estimation of attainable speeds as well as the relative speed between conflicting traffic movements and between consecutive geometric elements on each fastest path. Recommended maximum theoretical entry design speeds $\left(\mathrm{V}_{1}\right)$ depend on the roundabout type: for single-lane roundabouts, this speed is $40 \mathrm{~km} / \mathrm{h}$, and for multi-lane roundabouts 40 to $50 \mathrm{~km} / \mathrm{h}$ [68].

In the first part of the research, the validation of VAR-1 and VAR-2 models was conducted by comparing observed and simulated sound pressure levels at the receivers placed in the vicinity of three roundabouts located in the suburban area of Zagreb, Croatia. Basic geometric and design elements of these intersections are given in Table 1, and their plan view is shown in Figure 2.

Table 1. Basic geometric and design elements of analyzed roundabouts.

\begin{tabular}{|c|c|c|c|c|}
\hline Intersection & $\begin{array}{l}\text { Inscribed Circle } \\
\text { Radius (m) }\end{array}$ & Approach Legs & $\begin{array}{c}\text { Circulatory Roadway } \\
\text { Width (m) }\end{array}$ & $\begin{array}{c}\text { Number of Lanes on } \\
\text { the Circulatory } \\
\text { Roadway }\end{array}$ \\
\hline ROUNDABOUT-1 & 32 & $\begin{array}{l}2 \text { two-lane } \\
1 \text { single-lane }\end{array}$ & 13.5 & 2 \\
\hline ROUNDABOUT-2 & 23 & 3 two-lane & 11.0 & 1 \\
\hline ROUNDABOUT-3 & 25 & 4 two-lane & 10.0 & 1 \\
\hline
\end{tabular}

The receivers were placed along the roundabout entrance (approach link), the circulatory roadway, and the roundabout exit (next departure link). Short-term $15 \mathrm{~min}$ measurements of the noise levels were carried out by Brüel \& Kjær hand-held analyzers and sound level meters type 2270, 2260, and 2250 (manufacturer Brüel \& Kjær Sound \& Vibration Measurement A/S, DK-2850 Nærum, Denmark). Field measurements of noise and traffic were carried out from 14:10 to 17:20, as it was observed during research location scouting that in this period undersaturated traffic flow conditions prevailed, upstream signals enabled uniform approach platooning, there was no queuing in the approach traffic streams, and progression was fair on all three roundabouts. Noise measurements were carried out under favorable meteorological conditions (according to the norm ISO 19962:2017 [72]), at the height of $1.2 \mathrm{~m}$ above the ground surface, and approximately $10 \mathrm{~m}$ from the axis of the closest traffic lane. At each measuring point, measurements were repeated three times.

Data on the road traffic load and the percentage of heavy vehicles for each direction of movement (Table 2), as well as average speed for each noise source segment (Figure 2), were determined using hourly video recording of the traffic, which was conducted during noise measurements. Traffic flow during measurements was continuous. Data on the remaining noise emission and propagation parameters (road surface type, the longitudinal slope of road, relief, ground surface type, barrier, and building height and material) was collected during the field measurements and consolidated in a digital 3D terrain model that was based on the available digital maps. 


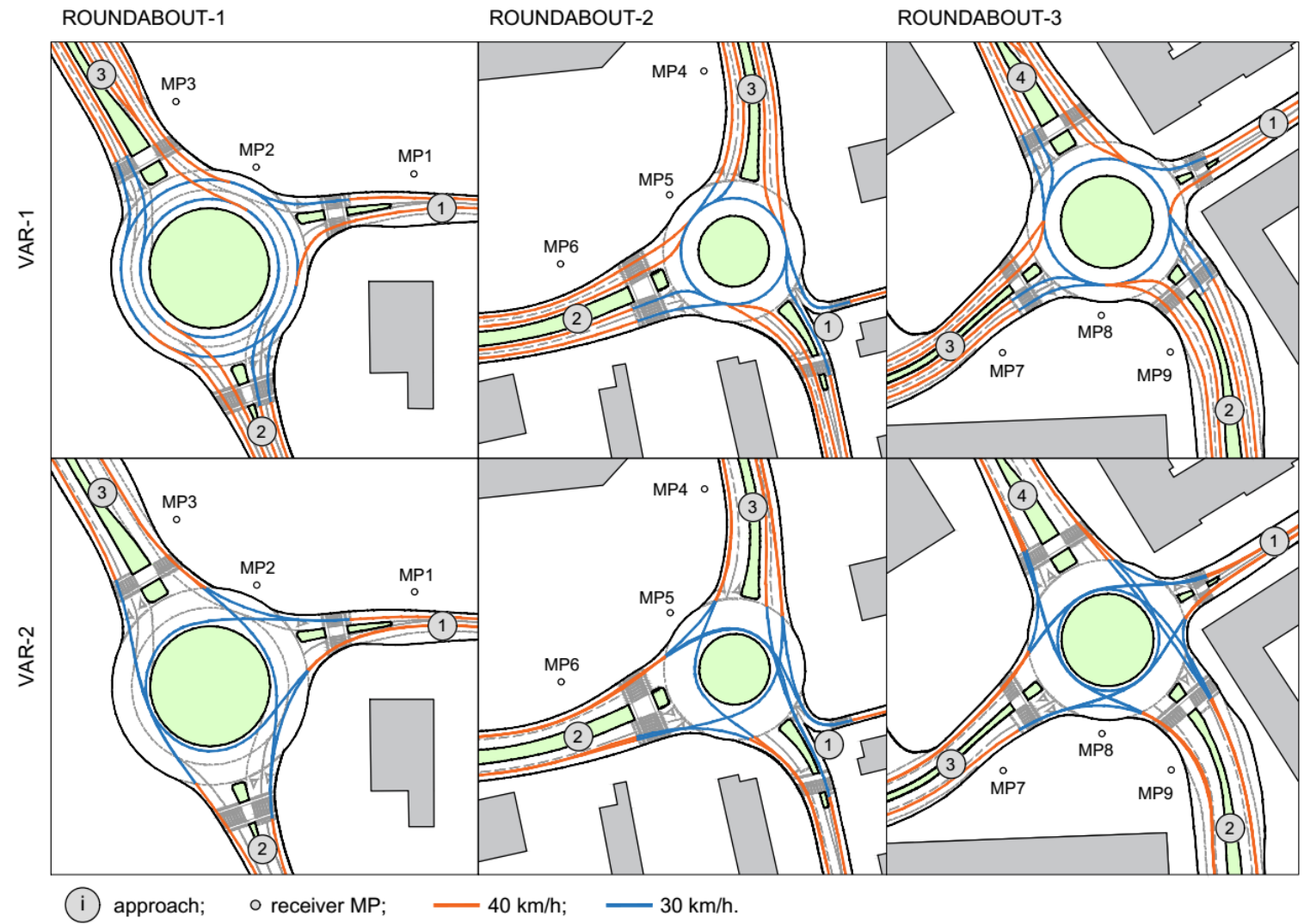

Figure 2. Plan view of the analyzed intersections and the average speed for each noise source segment in VAR-1 and VAR2 model.

Table 2. Road traffic load and the percentage of heavy vehicles.

\begin{tabular}{cccc}
\hline Intersection & Movement Direction & $\begin{array}{c}\text { Traffic Load } \\
\text { (Vehicle/Hour) }\end{array}$ & $\begin{array}{c}\text { Percentage of Heavy } \\
\text { Vehicles (\%) }\end{array}$ \\
\hline \multirow{2}{*}{ ROUNDABOUT-1 } & $1-2$ & 56 & 19 \\
& $1-3$ & 139 & 10 \\
& $2-1$ & 39 & 7 \\
& $2-3$ & 209 & 20 \\
& $3-1$ & 164 & 8 \\
ROUNDABOUT-2 & $3-2$ & 300 & 6 \\
& $1-2$ & 95 & 4 \\
& $1-3$ & 277 & 4 \\
& $2-1$ & 68 & 2 \\
& $2-3$ & 171 & 4 \\
& $3-1$ & 412 & 5 \\
& $3-2$ & 153 & 0 \\
& $1-2$ & 28 & 4 \\
& $1-3$ & 25 & 2 \\
& $1-4$ & 101 & 0 \\
& $2-1$ & 85 & 6 \\
& $2-3$ & 80 & 3 \\
& $2-4$ & 300 & 2 \\
& $3-1$ & 47 & 2 \\
& $3-2$ & 85 & 3 \\
& $3-4$ & 216 & 4 \\
& $4-1$ & 285 & 2 \\
\hline
\end{tabular}


The calculation of equivalent noise levels for the period "day" was conducted using specialized noise prediction software LimA v 5.2 at the height of $1.2 \mathrm{~m}$ (due to the comparison to field measurement results) using two modified RLS-90 models. In the first modified model (VAR-1), noise sources were situated on the axis of each lane, while in the second modified model (VAR-2), noise sources were placed on the vehicle movement trajectories.

In the second part of the research, to investigate the impact of deflection and relative speed on simulated noise levels, seven single-lane roundabouts with different speed profiles were modeled with the VAR-2 method. Basic geometric and design elements of analyzed roundabouts, the fastest path segments, the direction of translatory movement, and the position of the receivers are shown in Figure 3. Different speed profiles were achieved by varying the deflection of the central island (d) from 8 to $16 \mathrm{~m}$. The variations in the deflection values (d) were achieved by the translatory movements $(\Delta)$ of approaches 1 and 3 from the center of the circular island in the direction of a straight parallel to the axis of approaches 2 and 4, as shown in Figure 3, in which the roundabout with the deflection value of $8 \mathrm{~m}$ is presented (roundabout model 6). This resulted in the construction of the seven fastest paths for the straight passage of the vehicle. On each path, five segments were defined (Figure 3). On segments 2,3, and 4 the design speed was determined based on the speed-radius relationship (2), while on the segments 1 and 5 the design speed was set to $50 \mathrm{~km} / \mathrm{h}$.

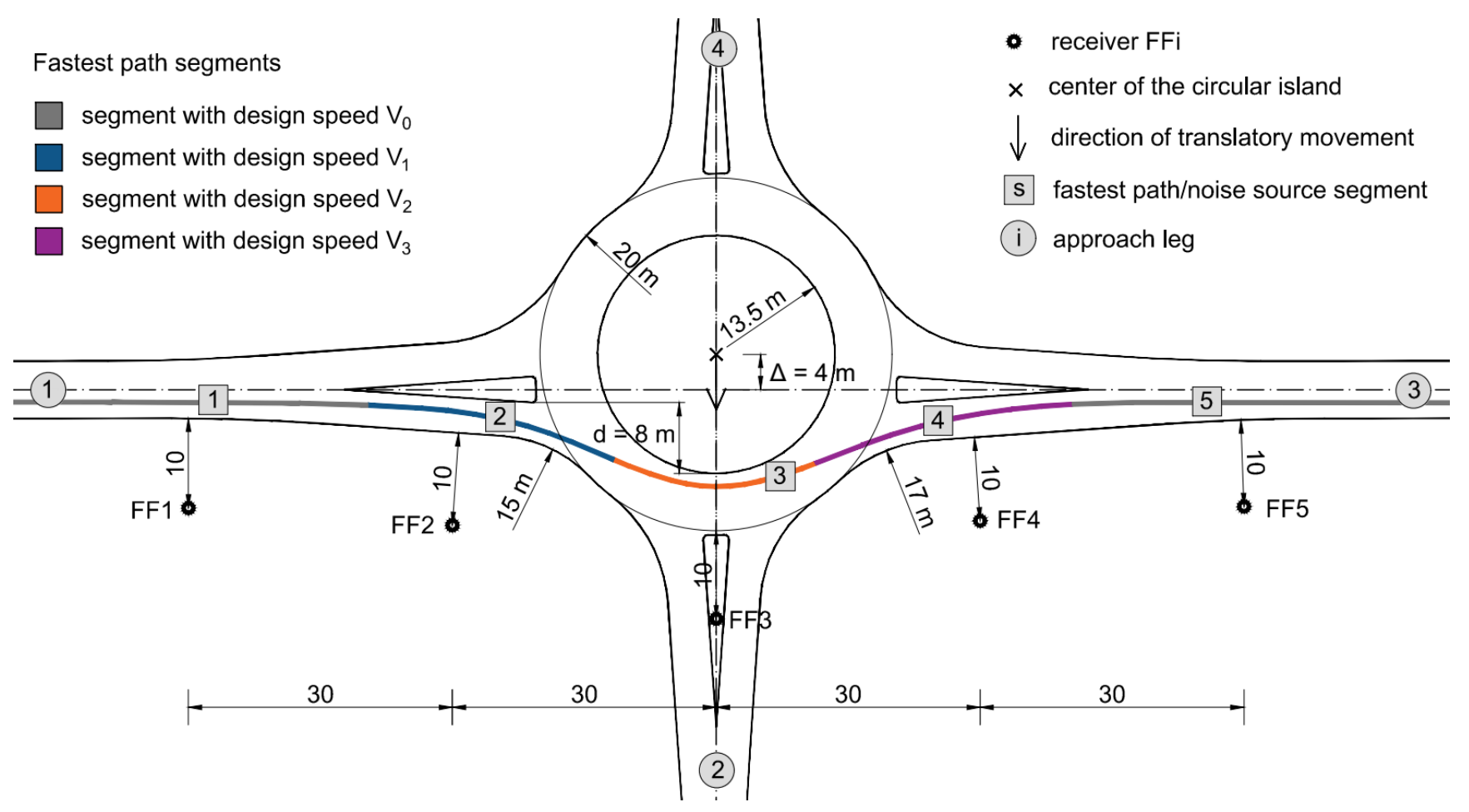

Figure 3. Basic geometric and design elements, fastest path segments, the direction of translatory movement, and the position of the receivers (roundabout model 6: $\mathrm{d}=8 \mathrm{~m}, \Delta=4 \mathrm{~m}$ ).

The design speed of each segment was used in the calculation of noise levels at five receivers placed along each analyzed fastest path. These receivers were placed $30 \mathrm{~m}$ apart, at $10 \mathrm{~m}$ from the carriageway edge, as shown in Figure 3. Direction and values of translatory movements $(\Delta)$, the design speed for each trajectory segment $\left(\mathrm{V}_{\mathrm{i}}\right)$, and the relative speed between consecutive elements of the constructed fastest paths that were used in the noise calculations are given in Table 3. 
Table 3. Direction and values of translatory movements, the design speed for each trajectory segment and the relative speed between consecutive elements of the analyzed fastest paths.

\begin{tabular}{cccccccccc}
\hline \multirow{2}{*}{ Fastest Path } & \multirow{\Delta}{*}{$(\mathbf{m})$} & \multicolumn{3}{c}{ Design Speed $(\mathbf{k m} / \mathbf{h})$} & \multicolumn{4}{c}{ Relative Speed (km/h) } \\
\cline { 2 - 9 } & & $\mathbf{V}_{\mathbf{0}}$ & $\mathbf{V}_{\mathbf{1}}$ & $\mathbf{V}_{\mathbf{2}}$ & $\mathbf{V}_{\mathbf{3}}$ & $\mathbf{V}_{\mathbf{0}}-\mathbf{V}_{\mathbf{1}}$ & $\mathbf{V}_{\mathbf{1}}-\mathbf{V}_{\mathbf{2}}$ & $\mathbf{V}_{\mathbf{3}}-\mathbf{V}_{\mathbf{2}}$ & $\mathbf{V}_{\mathbf{0}}-\mathbf{V}_{\mathbf{3}}$ \\
\hline T1 & 0 & 50 & 33 & 21 & 38 & 17 & 12 & 17 & 12 \\
T2 & +2 & 50 & 37 & 22 & 40 & 13 & 15 & 18 & 10 \\
T3 & -2 & 50 & 32 & 21 & 34 & 18 & 11 & 13 & 16 \\
T4 & +3 & 50 & 38 & 23 & 41 & 12 & 15 & 18 & 9 \\
T5 & -3 & 50 & 34 & 18 & 35 & 16 & 16 & 17 & 15 \\
T6 & +4 & 50 & 39 & 24 & 44 & 11 & 15 & 20 & 6 \\
T7 & -4 & 50 & 32 & 17 & 34 & 18 & 15 & 17 & 16 \\
\hline
\end{tabular}

According to [68], for vehicles to safely negotiate the roundabout, the maximum relative speed should be approximately 15 to $25 \mathrm{~km} / \mathrm{h}$, while according to [69] this value should be approximately 10 to $20 \mathrm{~km} / \mathrm{h}$. According to [32], to avoid negative impacts on drivers and on the road environment, the maximum relative speed on roundabouts should be less than $20 \mathrm{~km} / \mathrm{h}$. The relative speed between consecutive elements on the analyzed fastest paths varies from 6 to $20 \mathrm{~km} / \mathrm{h}$ (Table 3), which is below the abovementioned maximum values. The calculation of equivalent noise levels for the period "day" (from 7:00 to 19:00 h) was conducted using software LimA v 5.2 at the height of $1.5 \mathrm{~m}$ above ground level. Remaining noise model input data was as follows:

- Noise sources were placed at the height of $0.5 \mathrm{~m}$ above the road surface, on the fastest path movement trajectories derived for the straight passage through the intersection;

- The average hourly traffic flow for the period "day" was 30 vehicles [64];

- The percentage of heavy vehicles was set to $10 \%$ [64].

\section{Results}

In the first part of the research, the validation of the analyzed models (VAR-1 and VAR-2) was conducted by comparing measured and modeled noise levels at the receivers placed in the vicinity of three suburban roundabouts. These noise levels and the difference between them are given in Table 4. A comparison between measured and modeled noise levels at analyzed locations (Table 4), showed that the median difference was $1.9 \mathrm{~dB}(\mathrm{~A})$ for the VAR-1, and $1.2 \mathrm{~dB}(\mathrm{~A})$ for the VAR-2, and that all observed differences (errors) are smaller than $3 \mathrm{~dB}(\mathrm{~A})$. The median difference was used as a relevant measure of representativeness in this analysis due to the relatively small data sample. As shown in Table 4, the largest difference between modeled and measured noise levels for both models occurred at the measurement point MP7 (2.5 and $2.9 \mathrm{~dB}(\mathrm{~A}))$. This difference can be explained by the complexity of the real world near this measurement point (the complex geometry of the nearby facades and acoustically soft surfaces between the noise source and the receiver), which was not modeled. Both models over-predict noise levels at the receivers, which is favorable in terms of noise protection. Smaller differences between modeled and measured levels in the receivers that were placed in the vicinity of the circulatory roadway (MP2, MP5, and MP8) were observed for the VAR-2. At the same time, smaller differences at the receivers located in the vicinity of the roundabout entry and exit (MP3, MP4, MP6, MP7, and MP9) occurred for the VAR-1. This result was expected, due to the different position of noise sources and their traffic load in the analyzed models. Compared to the VAR-1, noise sources in the VAR-2 are closer to the receivers on roundabout entry and exit, and further away from the receivers placed by the circulatory roadway (Figure 2). Furthermore, in VAR-1, the traffic load is distributed equally over lanes on the approaches with more than one entry and exit lane (Figure 2), while in VAR-2 the entire traffic load on these approaches is concentrated on the noise source placed in the fastest path trajectory, $1.5 \mathrm{~m}$ from the carriageway edge. 
Table 4. Measured and modeled noise levels and the difference between them.

\begin{tabular}{|c|c|c|c|c|c|c|}
\hline \multirow{3}{*}{ Receiver } & \multicolumn{6}{|c|}{ Noise Levels $(\mathrm{dB}(\mathrm{A}))$} \\
\hline & \multirow{2}{*}{ Measured } & \multicolumn{2}{|c|}{ Modeled } & \multicolumn{3}{|c|}{ Difference } \\
\hline & & VAR-1 & VAR-2 & VAR-1-Measured & VAR-2-Measured & VAR-1-VAR-2 \\
\hline MP1 & 65.3 & 66.3 & 65.5 & 1.0 & 0.2 & 0.8 \\
\hline MP2 & 65.6 & 66.7 & 66.3 & 1.1 & 0.7 & 0.4 \\
\hline MP3 & 65.1 & 67.0 & 67.4 & 1.9 & 2.3 & -0.4 \\
\hline MP4 & 64.0 & 65.9 & 66.5 & 1.9 & 2.5 & -0.6 \\
\hline MP5 & 62.7 & 64.8 & 63.9 & 2.1 & 1.2 & 0.9 \\
\hline MP6 & 59.1 & 61.1 & 61.8 & 2.0 & 2.7 & -0.7 \\
\hline MP7 & 60.8 & 63.3 & 63.7 & 2.5 & 2.9 & -0.4 \\
\hline MP8 & 63.9 & 65.7 & 64.8 & 1.8 & 0.9 & 0.9 \\
\hline MP9 & 65.7 & 65.8 & 66.0 & 0.1 & 0.3 & -0.2 \\
\hline \multicolumn{4}{|c|}{ Median } & 1.9 & 1.2 & - \\
\hline
\end{tabular}

In the second part of the research, focused on the noise simulations conducted on the seven modeled four-legged single-lane roundabouts with different speed profiles, calculations showed that the noise source segments that contribute to the resulting noise levels in receivers FF1 and FF5 are segments 1 and 2, and segments 4 and 5 (shown on Figure 3), respectively, and that noise levels at the receivers FF2, FF3, and FF4 are influenced by all noise source segments. Results showed that the increase in the design speed did not result in higher noise levels at receivers FF1, FF2, FF4, and FF5 until the increase in the design speed reached $6 \mathrm{~km} / \mathrm{h}$ (Table 5 , T6). At the same time, only a slight decrease in entry and exit design speed (Table 5, T3) resulted in decreased noise levels at all receivers. The largest difference in noise levels was achieved at the receiver FF3, placed by the circulatory roadway. This result was expected because the design speed is the lowest on the section that is nearest to this receiver. At the receivers FF1 and FF5, which are furthest from the roundabout central island (center of the intersection), negligible changes in noise levels were recorded, even when the deviations of the design speed reached the maximum value.

Table 5. Deviations of the design speed and calculated noise levels.

\begin{tabular}{|c|c|c|c|c|c|c|c|c|c|}
\hline \multirow{2}{*}{ Fastest Path } & \multicolumn{4}{|c|}{ Design Speed Deviations (km/h) } & \multicolumn{5}{|c|}{ Noise Levels Deviations (dB(A)) } \\
\hline & $\Delta \mathbf{V}_{1}$ & $\Delta \mathbf{V}_{2}$ & $\Delta \mathbf{V}_{3}$ & Median & FF1 & FF2 & FF3 & FF4 & FF5 \\
\hline $\mathrm{T} 7$ & -1 & -4 & -4 & -4 & -0.1 & -0.2 & -0.9 & -0.2 & 0.0 \\
\hline $\mathrm{T} 5$ & 1 & -3 & -3 & -3 & -0.1 & 0.0 & -0.8 & -0.1 & 0.0 \\
\hline $\mathrm{T} 3$ & -1 & 0 & -4 & -1 & -0.1 & -0.2 & -0.6 & -0.3 & 0.0 \\
\hline $\mathrm{T} 1$ & 0 & 0 & 0 & 0 & 0.0 & 0.0 & 0.0 & 0.0 & 0.0 \\
\hline $\mathrm{T} 2$ & 4 & 1 & 2 & 2 & 0.0 & 0.0 & 0.0 & 0.0 & 0.0 \\
\hline $\mathrm{T} 4$ & 5 & 2 & 3 & 3 & 0.0 & 0.0 & 0.2 & 0.0 & 0.0 \\
\hline $\mathrm{T} 6$ & 6 & 3 & 6 & 6 & 0.2 & 0.2 & 0.6 & 0.2 & 0.1 \\
\hline
\end{tabular}

\section{Discussion}

Modeling road traffic noise at roundabouts is not incorporated in the established static noise modeling methods such as RLS-90 [53,54]. According to [73], another shortcoming of static noise models is that they are insensitive to traffic conditions (i.e., they are unable to capture the effects of transient queues under unsaturated traffic conditions and stop-and-go behaviors under saturated conditions). At the same time, they are considered unsuitable for estimating noise emissions from vehicle flows traveling below $30 \mathrm{~km} / \mathrm{h}$ [73]. Moreover, according to [52], static models usually underestimate the noise levels compared to the analytic and dynamic noise models. The main contribution of the research presented in this paper is the integration of the road traffic noise estimation at roundabouts in the established RLS-90 noise model. Namely, the first part of the research was focused on the validation of two noise models (VAR-1 and VAR-2) that suggest the modification of 
the static RLS-90 noise model intended for the noise calculations at roundabouts with unsaturated traffic flow. The modification included changing the plan position of noise sources, the definition of heavy vehicles, the definition of periods "day", "night", and "evening", and dividing the noise sources into segments that are defined by the observed average speed on each lane. These models were applied in the noise calculations at three suburban roundabouts with different geometric design features and dimensions, under unsaturated traffic conditions. Research results validated the proposed models and showed that they over-predict noise levels by $1.9 \mathrm{~dB}(\mathrm{~A})$ and $1.2 \mathrm{~dB}(\mathrm{~A})$, which is in line with the results of similar studies $[62,63,67]$. It was concluded that the VAR-2 model is more suitable for the application in road traffic noise calculations on roundabouts because the calculation results were closer to the measured values, and because it required a shorter preparation time compared to the VAR-1 model. Due to the relatively small data sample used in the validation of the models, future research should include more noise measurements on both suburban and urban roundabouts.

In the second part of the research, the VAR-2 model was applied for the noise calculations at roundabouts designed with different geometric elements to analyze the influence of the roundabout geometry on noise levels. Seven single-lane roundabouts with different speed profiles were modeled to investigate the impact of deflection and relative speed between consecutive elements of the vehicle movement trajectories on noise levels. The results of this part of the research indicated that for the analyzed roundabouts even a small change in the deflection around the central island had an influence on the noise levels generated by road traffic. Namely, the results showed that the decrease in deflection around the central island caused the increase in design speed on the fastest path segments on the entry, exit, and around the central island, which is in line with the previous studies on the vehicle speed on roundabouts $[33,74,75]$. The impact of this design speed increase on modeled noise levels was negligible until the median speed deviations reached $6 \mathrm{~km} / \mathrm{h}$ (deflection decrease of $4 \mathrm{~m}$ ). On the other hand, a slight decrease in speed (a median deviation of only $1 \mathrm{~km} / \mathrm{h}$ ), caused by the increase of the deflection around the central island of $2 \mathrm{~m}$, generated a decrease in modeled noise levels. Due to the small number of modeled roundabouts and fastest path trajectories, the impact of the relative speed between the consecutive elements of the vehicle movement trajectories on noise levels could not be quantified.

In future research, it is necessary to investigate whether there is an optimal relative speed that generates lower noise levels while maintaining a suitable ratio of geometric elements of roundabouts from the safety point of view. This will be done by modeling noise contributions at a larger number of roundabouts with different outer radii and deflection around the central island. Noise sources placed in the vehicle trajectories for movement into, through, and exiting the roundabout will be investigated for their individual and combined contribution to the noise levels. Moreover, the influence of the traffic flow and its composition will be taken into consideration, as more and more studies confirmed that these parameters significantly influence the impact of the intersection on noise levels $[41,46,76,77]$.

\section{Conclusions}

The introduction of modern roundabouts in road network has proved to be a good solution for reaching the transportation sustainability goals, but one should be aware that only a well-designed roundabout - the one whose geometry provides smooth traffic flow by minimizing the start-stop operations of drivers-will be effective as a noise abatement measure. The iterative process of roundabout design includes standard performance checks that ensure the smooth speed profile through the roundabout. These checks are the design vehicle swept path analysis, the definition of the fastest path, and visibility tests. When the results of performance checks are satisfactory in terms of roundabout operation and safety, the final design details of a roundabout are defined. 
Challenges that emerge in roundabout design are mostly related to space constrictions and provision of appropriate deflection around the central island. This can result in speed profiles on roundabouts that might reduce their potential as a noise abatement measure. Therefore, the impact on noise levels and its applicability as a traffic calming device should be investigated in the early design stage of roundabouts, by modeling road traffic noise levels. Established noise models used in noise prediction are either too complex for use in the preliminary design stage of roundabouts when the available input data is limited, or they do not even include intersection contribution to noise levels. At the same time, their creation can be rather time-consuming. This makes them less than optimal for use in noise predictions at roundabouts, as an optimal model is the one in which the reliability of the result is harmonized with the available input data, and the costs and time required to create a noise model.

In the research presented in this paper, modification of the established static RLS-90 road traffic noise model was proposed and validated. In the proposed modified model, intended for noise calculations at suburban roundabouts with unsaturated traffic flow, the following results of the fastest path performance check were utilized:

- Vehicle movement trajectories (for the position of road traffic noise sources), and

- Design speed (for noise calculations at roundabouts that are still in the design phase).

Research results showed that these modifications:

- Simplify the preparation procedure of the noise emission model;

- Result in a model that is closer to the real-world in terms of traffic flow conditions compared to the standard RLS-90 model;

- Allow the simulation of the impact of the intersection on the noise situation in the early stages of roundabout design, before the definition of the horizontal signalization, as the positions of the vehicle movement trajectories depend primarily on the carriageway edge; and

- $\quad$ Enable modeling the influence of roundabout deflection on calculated noise levels.

These modifications could encourage the optimization of roundabout geometry in its preliminary design phase not only in terms of safety, but also in terms of its noise reduction capabilities, and/or emissions in general. Furthermore, the results of the research presented in this paper demonstrated the influence of roundabout design concerning the achieved deflection around the central island on noise levels that cannot be overlooked. Future research will be focused on defining the optimal relative speed on a roundabout-one that will provide benefits in terms of its noise abatement capabilities while maintaining a suitable ratio of geometric elements of roundabouts from the safety and efficiency point of view.

Author Contributions: Conceptualization, S.A. and M.A.; methodology, S.A. and M.A.; validation, S.A., M.A., and J.D.; formal analysis, S.A. and M.A.; investigation, S.A. and J.D.; resources, V.D.; writing-original draft preparation, S.A.; writing-review and editing, M.A., J.D., and V.D.; supervision, V.D.; funding acquisition, V.D. All authors have read and agreed to the published version of the manuscript.

Funding: This research was funded by The Republic of Croatia, Ministry of Science and Education, grant number 082-1102147-2153.

Acknowledgments: Authors would like to acknowledge Stjepan Lakušić and Ivo Haladin for technical support and donations in time and measuring equipment.

Conflicts of Interest: The authors declare no conflict of interest. The funders had no role in the design of the study; in the collection, analyses, or interpretation of data; in the writing of the manuscript, or in the decision to publish the results. 


\section{References}

1. Litman, T. Developing Indicators for Comprehensive and Sustainable Transport Planning. Transp. Res. Rec. 2007, 2017, 10-15. [CrossRef]

2. Oleśków-Szłapka, J.; Pawłyszyn, I.; Przybylska, J. Sustainable Urban Mobility in Poznan and Oslo-Actual State and Development Perspectives. Sustainability 2020, 12, 6510. [CrossRef]

3. Ariniello, A.; Przybyl, B. Roundabouts and Sustainable Design. In Proceedings of the Green Streets and Highways 2010: An Interactive Conference on the State of the Art and How to Achieve Sustainable Outcomes, Denver, CO, USA, 14-17 November 2010; Weinstein, N., Ed.; American Society of Civil Engineers (ASCE): Reston, VA, USA, 2010. [CrossRef]

4. Hydén, C.; Várhelyi, A. The effects on safety, time consumption and environment of large scale use of roundabouts in an urban area: A case study. Accid. Anal. Prev. 2000, 32, 11-23. [CrossRef]

5. Lenters, M. Roundabout Planning and Design for Efficiency \& Safety Case study: Wilson Street/Meadowbrook Drive/Hamilton Drive, City of Hamilton. In Proceedings of the 2003 Annual Conference of the Transportation Association of Canada (TAC), St. John's, NL, Canada, 21-23 September 2003; Available online: http: / / conf.tac-atc.ca/english/resourcecentre/readingroom/ conference/conf2003/pages/title.html (accessed on 4 April 2021).

6. Lenters, M. Safety Auditing Roundabouts. In Proceedings of the 2004 Annual Conference of the Transportation Association of Canada (TAC), Québec City, QC, Canada, 19-22 September 2004; Available online: http:/ / conf.tac-atc.ca/english/resourcecentre/ readingroom/conference/conf2004/english/paper_by_title.htm (accessed on 4 April 2021).

7. Bergh, C.; Retting, R.A.; Myers, E. Continued Reliance on Traffic Signals: The Cost of Missed Opportunities to Improve Traffic Flow and Safety at Urban Intersections; Insurance Institute for Highway Safety: Arlington, VA, USA, 2005; Available online: https://www.iihs.org/topics/bibliography/ref/1848 (accessed on 4 April 2021).

8. Quartieri, J.; Mastorakis, N.E.; Guarnaccia, C.; Troisi, A.; D'Ambrosio, S.; Iannone, G. Road Intersections Noise Impact on Urban Environment Quality. In Proceedings of the 5th WSEAS International Conference on Recent Advances in Applied and Theoretical Mechanics, Puerto De La Cruz, Tenerife, Canary Islands, Spain, 14-16 December 2009.

9. Granà, A.; Giuffrè, T.; Guerrieri, M. Exploring Effects of Area-Wide Traffic Calming Measures on Urban Road Sustainable Safety. J. Sustain. Dev. 2010, 3, 38-49. [CrossRef]

10. Covaciu, D.; Florea, D.; Preda, I.; Timar, J. The Effect of Converting a Signalized Intersection into a Roundabout-A Case Study. In Proceedings of the International Congress on Automotive CAR-2011, Pitesti, Romania, 2-4 November 2011; Available online: http:/ /hdl.handle.net/123456789/216 (accessed on 4 April 2021).

11. Mensah, S.; Eshragh, S.; Faghri, A. Modern Roundabouts and Sustainable Intersection Design. In Proceedings of the 3rd International Conference on Roundabouts, TRB, Carmel, IN, USA, 18-20 May 2011.

12. Mauro, R.; Cattani, M. Functional and Economic Evaluations for Choosing Road Intersection Layout. Promet Traffic Transp. 2012, 24, 441-448. [CrossRef]

13. Guerrieri, M.; Corriere, F.; Casto, B.L.; Rizzo, G. A model for evaluating the environmental and functional benefits of "innovative" roundabouts. Transp. Res. Part D 2015, 39, 1-16. [CrossRef]

14. Guerrieri, M.; Corriere, F.; Rizzo, G.; Casto, B.L.; Scaccianoce, G. Improving the Sustainability of Transportation: Environmental and Functional Benefits of Right Turn By-Pass Lanes at Roundabouts. Sustainability 2015, 7, 5838-5856. [CrossRef]

15. Distefano, N.; Leonardi, S. Experimental investigation of the effect of roundabouts on noise emission level from motor vehicles. Noise Control Eng. J. 2019, 67, 282-294. [CrossRef]

16. Fernandes, P.; Teixeira, J.; Guarnaccia, C.; Bandeira, J.M.; Macedo, E.; Coelho, M.C. The Potential of Metering Roundabouts: Influence in Transportation Externalities. TRR J. Transp. Res. Board 2018, 2672, 21-34. [CrossRef]

17. Ahmed, H.; Easa, S. Optimization of single-lane roundabout geometric design: Environmental sustainability. In Proceedings of the CSCE 2018 Annual Conference, Fredericton, NB, Canada, 13-16 June 2018.

18. Bérengier, M. Acoustical impact of traffic flowing equipments in urban area. In Proceedings of the Forum Acusticum, Sevilla, Sevilla, Spain, 16-20 September 2002.

19. Mandavilli, S.; Russell, E.R.; Rys, M.J. Impact of Modern Roundabouts on Vehicular Emissions. In Proceedings of the 2003 Mid-Continent Transportation Research Symposium, Ames, IA, USA, 21-22 August 2003.

20. Bendtsen, H.; Haberl, J.; Litzka, J.; Pucher, E.; Sandberg, U.; Watts, G. Traffic Management and Noise Reducing PavementsRecommendations on Additional Noise Reducing Measures; Report 137; Danish Road Institute: Roskilde, Denmark, 2004.

21. Annecke, R.; Berge, T.; Crawshaw, S.; Ellebjerg, L.; Mårdh, S.; Pullwitt, E.; Steven, H.; Wiberg, A.; Zimmermann, U. Noise Reduction in Urban Areas from Traffic and Driver Management; EU Project Silence, Deliverable No. H.D2; Ellebjerg, H., Ed.; European Commission: Brussels, Belgium, 2005.

22. Desarnaulds, V.; Monay, G.; Carvalho, A. Noise reduction by urban traffic management. In Proceedings of the Journées d'Automne 2004—Société Suisse d'Acoustique, Jona, St. Gallen, Switzerland, 4-5 November 2004; Available online: https: //www.sga-ssa.ch/fr/herbsttagung-2004-2 (accessed on 4 April 2021).

23. Makarewicz, R.; Golebiewski, R. Modeling of the roundabout noise impact. J. Acoust. Soc. Am. 2007, 122, 860-868. [CrossRef]

24. Decký, M. Noise pollution from roundabout traffic in the outer environment of built-up areas of towns. Perner's Contacts 2009, 4 , 53-68. Available online: https:/ / pernerscontacts.upce.cz/index.php/perner/article/view/1183 (accessed on 4 April 2021).

25. Fernandes, P.M.; Fontes, T.; Neves, M.; Pereira, S.R.; Bandeira, J.; Rouphail, N.; Coelho, M. Assessment of Corridors with Different Types of Intersections. Transp. Res. Rec. 2015, 2503, 39-50. [CrossRef] 
26. Gardziejczyk, W.; Motylewicz, M. Noise level in the vicinity of signalized roundabouts. Transp. Res. Part. D 2016, 46, 128-144. [CrossRef]

27. Meneguzzer, C.; Gastaldi, M.; Arboretti Giancristofaro, R. Before-and-After Field Investigation of the Effects on Pollutant Emissions of Replacing a Signal-Controlled Road Intersection with a Roundabout. J. Adv. Transp. 2018, 2018, 3940362. [CrossRef]

28. Jandacka, D.; Decky, M.; Durcanska, D. Traffic Related Pollutants and Noise Emissions in the Vicinity of Different Types of Urban Crossroads. IOP Conf. Ser. Mater. Sci. Eng. 2019, 661, 012152. [CrossRef]

29. European Environment Agency (EEA). Managing Exposure to Noise in Europe. Briefing January 2017. Available online: https:/ / www.eea.europa.eu/publications/managing-exposure-to-noise-in-europe (accessed on 2 May 2020).

30. Robertson, S.; Ward, H.; Marsden, G.; Sandberg, U.; Hammerstrom, U. The Effect of Speed on Noise, Vibration and Emissions from Vehicles; Working Paper 1.2.1 for the Master Project Funded by the European Commission (Contract No RO-96-SC.202); European Commission: Brussels, Belgium, 1998.

31. Covaciu, D.; Florea, D.; Timar, J. Estimation of the Noise Level Produced by Road Traffic in Roundabouts. Appl. Acoust. 2015, $98,43-51$. [CrossRef]

32. Brindle, R.E. Speed-Based Design of Traffic Calming Schemes. In Proceedings of the ITE 2005 Annual Meeting and Exhibit Compendium of Technical Papers, Melbourne, Australia, 7-10 August 2005.

33. Davidović, S.; Bogdanović, V.; Garunović, N.; Papić, Z.; Pamučar, D. Research on Speeds at Roundabouts for the Needs of Sustainable Traffic Management. Sustainability 2021, 13, 399. [CrossRef]

34. Coelho, M.C.; Farias, T.L.; Rouphail, N.M. Effect of roundabout operations on pollutant emissions. Transp. Res. Part D 2006, 11, 333-343. [CrossRef]

35. Chamberlin, R.; Swanson, B.; Talbot, E.; Dumont, J.; Pesci, S. Analysis of MOVES and CMEM for evaluating the emissions impacts of an intersection control change. In Proceedings of the TRB 90th Annual Meeting: Current Environmental Issues in Transportation, Washington, DC, USA, 23-27 January 2011.

36. Ahn, K.; Kronprasert, N.; Rakha, H. Energy and Environmental Assessment of High-Speed Roundabouts. Transp. Res. Rec. 2009, 2123, 54-65. [CrossRef]

37. Waters, P.E. Control of road noise by vehicle operation. J. Sound Vib. 1970, 13, 445-453. [CrossRef]

38. Lewis, P.T.; James, A. On the noise emitted by single vehicles at roundabouts. J. Sound Vib. 1978, 58, 293-299. [CrossRef]

39. Hallmark, S.L.; Wang, B.; Mudgal, A.; Isebrands, H. On-Road Evaluation of Emission Impacts of Roundabouts. TRR J. Transp. Res. Board 2011, 2265, 226-233. [CrossRef]

40. Lu, X.; Kang, J.; Zhu, P.; Cai, J.; Guo, F.; Zhang, Y. Influence of Urban Road Characteristics on Traffic Noise. Transp. Res. Part D Transp. Environ. 2019, 75, 136-155. [CrossRef]

41. Trollé, A.; Terroir, J.; Lavandier, C.; Marquis-Favre, C.; Lavandier, M. Impact of urban road traffic on sound unpleasantness: A comparison of traffic scenarios at crossroads. Appl. Acoust. 2015, 94, 46-52. [CrossRef]

42. Campolieti, D.; Bertoni, D. The Action Plan for Noise Reduction in Modena: Methods, Effects and Perspectives. Radiat. Prot. Dosim. 2009, 137, 252-255. [CrossRef]

43. Guarnaccia, C. Acoustical Noise Analysis in Road Intersections: A Case Study. Recent advances in Acoustics and Music. In Proceedings of the 11th WSEAS International Conference on Acoustics E Music: Theory E Applications (AMTA '10); WSEAS Press: Athens, Greece, 2010; pp. 208-215.

44. Estévez-Mauriz, L.; Forssén, J.; Kropp, W.; Zachos, G. Isolating Key Features in Urban Traffic Dynamics and Noise Emission: A Study on a Signalized Intersection and a Roundabout. In Proceedings of the 45th International Congress and Exposition on Noise Control Engineering (Internoise 2016): Towards a Quieter Future, Hamburg, Germany, 21-24 August 2016; Deutsche Gesellschaft für Akustik (DEGA): Berlin, Germany, 2016; pp. 7197-7208.

45. Estévez-Mauriz, L.; Forssén, J. Dynamic traffic noise assessment tool: A comparative study between a roundabout and a signalised intersection. Appl. Acoust. 2018, 130, 71-86. [CrossRef]

46. Li, F.; Lin, Y.; Cai, M.; Du, C. Dynamic simulation and characteristics analysis of traffic noise at roundabout and signalized intersections. Appl. Acoust. 2017, 121, 14-24. [CrossRef]

47. Jaworski, A.; Mądziel, M.; Lejda, K. Creating an emission model based on portable emission measurement system for the purpose of a roundabout. Environ Sci. Pollut. Res. 2019, 26, 21641-21654. [CrossRef]

48. Pigasse, G. Traffic Flow and Noise: A Method Study; Report 180-2010, Road Directorate; Danish Road Institute: Roskilde, Denmark, 2010; ISBN 978-87-92094-63-6.

49. Salamati, K.; Rouphail, N.M.; Frey, H.C.; Liu, B.; Schroeder, B.J. Simplified Method for Comparing Emissions in Roundabouts and at Signalized Intersections. Transp. Res. Rec. J. Transp. Res. Board 2015, 2517, 48-60. [CrossRef]

50. To, W.M.; Chan, T.M. The noise emitted from vehicles at roundabouts. J. Acoust. Soc. Am. 2000, 107, 2760-2763. [CrossRef]

51. Steele, C. A critical review of some traffic noise prediction models. Appl. Acoust. 2001, 62, 271-287. [CrossRef]

52. Chevallier, E.; Can, A.; Nadji, M.; Leclercq, L. Improving noise assessment at intersections by modeling traffic dynamics. Transp. Res. Part D 2009, 14, 100-110. [CrossRef]

53. Probst, W. Accuracy and Precision in Traffic Noise Prediction. In Proceedings of the Internoise 2010 Noise and Sustainability, Lisbon, Portugal, 13-16 June 2010; Available online: https:/ /www.datakustik.com/e-learning-center/papers-publications / (accessed on 4 April 2021). 
54. Garg, N.; Maji, S. A critical review of principal traffic noise models: Strategies and implications. Environ. Impact Assess. Rev. 2014, 46, 68-81. [CrossRef]

55. Can, A.; Leclercq, L.; Lelong, J. Dynamic estimation of urban traffic noise: Influence of traffic and noise source representations. Appl. Acoust. 2008, 69, 858-867. [CrossRef]

56. Can, A.; Leclercq, L.; Lelong, J.; Defrance, J. Capturing urban traffic noise dynamics through relevant descriptors. Appl. Acoust. 2008, 69, 1270-1280. [CrossRef]

57. Can, A.; Leclercq, L.; Lelong, J.; Defrance, J. Accounting for traffic dynamics improves noise assessment: Experimental evidence. Appl. Acoust. 2009, 70, 821-829. [CrossRef]

58. Can, A.; Chevallier, E.; Nadji, M.; Leclercq, L. Dynamic Traffic Modeling for Noise Impact Assessment of Traffic Strategies. Acta Acust. United Acust. 2010, 96, 482-493. [CrossRef]

59. Guarnaccia, C. Advanced Tools for Traffic Noise Modelling and Prediction. WSEAS Trans. Syst. 2013, 2, 121-130. Available online: https:/ / www.wseas.org/wseas/cms.action?id=6952 (accessed on 5 April 2021).

60. Zhang, X.; Kuehnelt, H.; De Roeck, W. Traffic Noise Prediction Applying Multivariate Bi-Directional Recurrent Neural Network. Appl. Sci. 2021, 11, 2714. [CrossRef]

61. Probst, W. Accuracy and precision of prediction models for road noise. In Proceedings of the EuroNoise 2009, Edinburgh, UK, 26-29 October 2009.

62. Dragčević, V.; Ahac, S.; Stančerić, I. Experience in estimation of road traffic noise situation in urban zone. In Proceedings of the 16th International Congress on Sound \& Vibration, Recent Developments in Acoustics, Noise and Vibration, Krakow, Poland, 5-9 July 2009.

63. Džambas, T.; Dragčević, V.; Čuljak, J. Monitoring of traffic noise on urban road intersection-A Case Study. In Proceedings of the 5th International Conference on Road and Rail Infrastructure, Zadar, Croatia, 17-19 May 2018; Available online: https: //master.grad.hr/cetra/ocs/index.php/cetra5/cetra2018/schedConf/presentations (accessed on 5 April 2021).

64. Der Bunderminister für Verkehr. Richtlinien für den Lärmschutz an Strassen; RLS-90; Der Bunderminister für Verkehr: Bonn, Germany, 1990.

65. Quartieri, J.; Mastorakis, N.E.; Iannone, G.; Guarnaccia, C.; D'Ambrosio, S.; Troisi, A.; Lenza, T.L.L. A Review of Traffic Noise Predictive Models. In Recent Advances in Applied and Theoretical Mechanics, Proceedings of the 5th WSEAS International Conference, Puerto De La Cruz, Tenerife, Canary Islands, Spain, 14-16 December 2009; Bulucea, C.A., Mladenov, V., Pop, E., Leba, M., Mastorakis, N., Eds.; WSEAS Press: Athens, Greece, 2009.

66. Eur-Lex. Directive 2002/49/EC of the European Parliament and of the Council of 25 June 2002 Relating to the Assessment and Management of Environmental Noise; OJ L 189; European Union: Brussels, Belgium, 2002.

67. Ahac, S.; Dragčević, V. Road traffic noise modeling at roundabouts. In Proceedings of the 2nd International Conference on Road and Rail Infrastructure CETRA 2012, Dubrovnik, Croatia, 7-9 May 2012; Available online: https:/ / master.grad.hr/cetra/ocs/ index.php/cetra/cetra2012/schedConf/presentations (accessed on 5 April 2021).

68. The National Academies of Sciences, Engineering and Medicine. Roundabouts: An Informational Guide, 2nd ed.; Report 672; Transportation Research Board: Washington, DC, USA, 2010.

69. Serbian Ministry of Infrastructure. Pravilnik o Uslovima Koje Sa Aspekta Bezbednosti Saobraćaja Moraju Da Ispunjavaju Putni Objekti i Drugi Elementi Javnog Puta; br. 50/2011; Službeni Glasnik RS: Belgrade, Serbia, 2011.

70. Ahac, S.; Džambas, T.; Stančerić, I.; Dragčević, V. Performance checks as prerequisites for environmental benefits of roundabouts. In Proceedings of the 3rd International Conference on Road and Rail Infrastructure CETRA 2014, Split, Croatia, 28-30 April 2014; Available online: https:/ / master.grad.hr/cetra/ocs/index.php/cetra3/cetra2014/schedConf/presentations (accessed on 5 April 2021).

71. American Association of State Highway and Transportation Officials. A Policy on Geometric Design of Highways and Streets, 7th ed.; American Association of State Highway and Transportation Officials: Washington, DC, USA, 2018.

72. International Organization for Standardization (ISO). Acoustics—Description, Measurement and Assessment of Environmental NoisePart 2: Determination of Sound Pressure Levels; ISO 1996-2:2017; ISO: Geneva, Switzerland, 2017.

73. Can, A. Dynamic Approaches for the Characterization and Mitigation of Urban Sound Environments. Ph.D. Thesis, Université du Maine, Le Mans, France, 2019. Available online: https:/ / hal.archives-ouvertes.fr/tel-02318710/ (accessed on 4 April 2021).

74. Pilko, H.; Brčić, D.; Šubić, N. Study of vehicle speed in the design of roundabouts. Gradjevinar 2014, 4, 407-416.

75. Šurdonja, S.; Dragčević, V.; Deluka-Tibljaš, A.; Korlaet, Ž. Model of vehicle path radius at roundabout center. Gradjevinar 2010, 71, 163-175.

76. Zefreh, M.M.; Torok, A. Theoretical Comparison of the Effects of Different Traffic Conditions on Urban Road Traffic Noise. J. Adv. Transp. 2018, 2018, 7949574. [CrossRef]

77. Fernandes, P.; Tomás, R.; Acuto, F.; Pascale, A.; Bahmankhah, B.; Guarnaccia, C.; Granà, A.; Coelho, M.C. Impacts of roundabouts in suburban areas on congestion-specific vehicle speed profiles, pollutant and noise emissions: An empirical analysis. Sustain. Cities Soc. 2020, 62, 102386. [CrossRef] 